\title{
In vitro antimicrobial activity of irreversible hydrocolloid impressions against 12 oral microorganisms
}

\author{
Atividade antimicrobiana in vitro de moldes \\ de hidrocolóide irreversível contra 12 \\ microrganismos orais
}

\section{Luciana Assirati Casemiro(a) Fernanda de Carvalho Panzeri Pires-de-Souza(b) Heitor Panzeri(b) Carlos Henrique Gomes Martins(c) Isabel Yoko Ito(d)}

(a) $\mathrm{PhD}$, School of Dentistry of Franca; (c) $\mathrm{PhD}$, Laboratory of Microbiology - University of Franca.

(b) PhDs, School of Dentistry of Ribeirão Preto; (d) PhD, School of Pharmaceutical Sciences of Ribeirão Preto - University of São Paulo.

Corresponding author:

Luciana Assirati Casemiro

Av. Caramuru, 2100 - Apto. 901

Ribeirão Preto - SP - Brazil

CEP: 14030-000

E-mail: lucianacasemiro@hotmail.com

\begin{abstract}
This study evaluated in vitro the antimicrobial activity of irreversible hydrocolloids (one containing an antimicrobial agent) prepared with water or with a $0.2 \%$ chlorhexidine digluconate solution against 12 strains of the oral microbiota. Twenty specimens $(0.5 \times 1.0 \mathrm{~cm})$ for each group (1. Jeltrate mixed with water; 2. Jeltrate mixed with $0.2 \%$ chlorhexidine digluconate solution; 3 . Greengel mixed with water; 4 . Greengel mixed with $0.2 \%$ chlorhexidine digluconate solution) were prepared under sterile conditions and placed in culture media inoculated with the indicator strains. After incubation in aerobiosis or microaerophilia, inhibition of the microbial growth was measured and the results were interpreted. The normal adherence curve revealed a non-normal distribution of the data, so the non-parametric Friedman Test was performed $(\mathrm{p}<0.05)$. The antimicrobial activity of the groups was classified in the following order: $1,3,4$, and 2 . The results suggest that the method of preparing irreversible hydrocolloids with a $0.2 \%$ digluconate chlorhexidine solution is more effective than the incorporation of an antimicrobial agent in the powder to reduce cross-contamination caused by impressions.
\end{abstract}

Descriptors: Alginates; Infection control, dental.

Resumo: Este trabalho avaliou in vitro a atividade antimicrobiana de alginatos (um deles contendo agente antimicrobiano) manipulados com água ou solução de digluconato de clorexidina a $0,2 \%$ contra 12 cepas da microbiota oral. Vinte espécimes $(0,5 \times 1,0 \mathrm{~cm})$ para cada grupo (1. Jeltrate manipulado com água, 2. Jeltrate manipulado com solução de digluconato de clorexidina a $0,2 \% ; 3$. Greengel manipulado com água; 4. Greengel manipulado com solução de digluconato de clorexidina a $0,2 \%$ ) foram confeccionados sob condições estéreis e semeados em meios de cultura inoculados com as cepas indicadoras. Após incubação em aerobiose ou microaerofilia, a inibição do crescimento microbiano foi medida e os resultados foram interpretados. A curva normal de aderência revelou uma distribuição não-normal dos dados, então o teste não paramétrico de Friedman $(p<0,05)$ foi realizado. A atividade antimicrobiana dos grupos foi classificada na seguinte ordem crescente: $1,3,4$ e 2 . Os resultados sugerem que a manipulação de alginatos com solução de digluconato de clorexidina a $0,2 \%$ é um método efetivo para reduzir a contaminaçãocruzada causada pelos moldes, mais que a incorporação do agente antimicrobiano no pó. Descritores: Alginatos; Controle de infecções dentárias. 


\section{Introduction}

The dental community has been showing a growing concern toward the transmission of pathogenic agents to professionals involved in the manufacturing of dental prostheses, orthodontic devices and other appliances used in rehabilitation treatments. There is a general agreement that impressions constitute one of the main vectors in the chain of infection. ${ }^{11,21}$ As of the 1970's, several studies have been developed with the purpose of establishing protocols to reduce the contamination of impressions before making gypsum casts. The impression material properties should be preserved, irrespective of the disinfection method used. ${ }^{9}$ Hence, compatibility with the several impression materials offered by the available methods to reduce microbial load remains a concern.

Among the impression materials, irreversible hydrocolloids are among the most commonly used and also among the most criticized in terms of its disinfection process. Inherent limitations, ${ }^{14}$ such as the material's dimensional instability, set restrictions to the treatment period as well as for choosing the antimicrobial agent. Due to its hydrophilic nature, also responsible for the highest retention of bacteria, ${ }^{14}$ disinfection should be carried out with a product that requires the least amount of time for the disinfection process. ${ }^{3}$ Antimicrobial agents are applied to irreversible hydrocolloid impressions in the following ways: sprays, which do not completely expose the contaminated surface to the antimicrobial agent, resulting in a less reliable procedure; ${ }^{3,21}$ immersions, ${ }^{1,3,9,10,17}$ which are not considered ideal, as there may be imbibition of the gel, swelling, and change of its physical dimensions; ${ }^{3}$ incorporation of the agent to the impression material; ;,7,15,18 and mixture with antimicrobial solutions instead of water. ${ }^{12,13,16}$ Few studies have addressed the mixture of antimicrobial solutions. The available data report that reliability is preserved in copies, and inform the working time of irreversible hydrocolloids mixed with a $0.2 \%$ solution of chlorhexidine digluconate. ${ }^{13}$ Moreover, studies have verified the antimicrobial activity of the mixtures against bacteria of the oral environment. ${ }^{16}$

Chlorhexidine is a cationic agent with broad- spectrum antibacterial and antifungal activities. It is also biocompatible with mouth tissues. It has substantivity, which is the ability to remain on a particular surface and be gradually released. ${ }^{19,20}$ Its excellent properties have motivated its increasing use in dentistry.

This study evaluated in vitro the antimicrobial activity of irreversible hydrocolloid impressions subjected to two forms of application of an antimicrobial agent (chlorhexidine): incorporation into the formulation of the powder, and mixture with the irreversible hydrocolloid. The association of both methods was also evaluated to assess if the antimicrobial activity was enhanced.

\section{Materials and Methods}

The antimicrobial activity of the irreversible hydrocolloids (Jeltrate ${ }^{\circledR}$, Dentsply Indústria e Comércio Ltda., Petrópolis, RJ, Brazil, and Greengel ${ }^{\circledR}$, Herpo Produtos Dentários Ltda., Rio de Janeiro, RJ, Brazil, with $0.05 \%$ diacetate chlorhexidine) was assessed by the diffusion technique in solid media, ${ }^{2}$ performed in triplicate. Standard strains (American Type Culture Collection, Manassas, VA, USA), as well as field strains (Laboratory of Microbiology, School of Pharmaceutical Sciences of Ribeirão Preto, University of São Paulo, Ribeirão Preto, SP, Brazil), and the culture media used for the test are shown on Table 1. The materials were processed $(30.0 \mathrm{~g}$ of powder to $36.0 \mathrm{ml}$ of liquid) and mixed for 60 seconds with sterile distilled water or $0.2 \%$ aqueous solution of chlorhexidine digluconate (Química Mundial, Ribeirão Preto, SP, Brazil), three times for each group, according to the test groups (Table 2). Group 1, with no antimicrobial agent in the powder or liquid, was the control. The mixed irreversible hydrocolloids were poured in a metallic matrix with holes $(0.5 \times 1.0 \mathrm{~cm})$, where they remained for the gelation time ( 2 minutes and 30 seconds). The 144 specimens were then removed and stored in sterile Petri dishes (Descarplas Indústria e Comércio Ltda., São Paulo, SP, Brazil), and remained there until inoculation.

Streptococcus mutans.1, Streptococcus mutans.2, Streptococcus sobrinus.1, Streptococcus sobrinus.2, and Enterococcus faecalis ATCC 10541 
Table 1 - Microorganisms, their characteristics and culture media used in the assessment of antimicrobial activity.

\begin{tabular}{|c|c|c|c|}
\hline \multirow{2}{*}{ Microorganism } & \multirow{2}{*}{ Characteristic } & \multicolumn{2}{|c|}{ Culture media } \\
\hline & & Inoculum & Test \\
\hline $\begin{array}{l}\text { Streptococcus mutans. } 1 \\
\text { Field strain }\end{array}$ & $\begin{array}{l}\text { Gram-positive } \\
\text { cocci }\end{array}$ & $\mathrm{BHI}$ & BHla \\
\hline $\begin{array}{l}\text { Streptococcus mutans. } 2 \\
\text { Field strain }\end{array}$ & $\begin{array}{l}\text { Gram-positive } \\
\text { cocci }\end{array}$ & $\mathrm{BHI}$ & $\mathrm{BHla}$ \\
\hline $\begin{array}{l}\text { Streptococcus sobrinus. } 1 \\
\text { Field strain }\end{array}$ & $\begin{array}{l}\text { Gram-positive } \\
\text { cocci }\end{array}$ & $\mathrm{BHI}$ & $\mathrm{BHla}$ \\
\hline $\begin{array}{l}\text { Streptococcus sobrinus. } 2 \\
\text { Field strain }\end{array}$ & $\begin{array}{l}\text { Gram-positive } \\
\text { cocci }\end{array}$ & $\mathrm{BHI}$ & $\mathrm{BHla}$ \\
\hline $\begin{array}{l}\text { Enterococcus faecalis } \\
\text { ATCC } 10541\end{array}$ & $\begin{array}{l}\text { Gram-positive } \\
\text { cocci }\end{array}$ & $\mathrm{BHI}$ & $\mathrm{BHla}$ \\
\hline $\begin{array}{l}\text { Staphylococcus epidermidis } \\
\text { Field strain }\end{array}$ & $\begin{array}{l}\text { Gram-positive } \\
\text { cocci }\end{array}$ & $\mathrm{MHb}$ & $\mathrm{MH}$ \\
\hline $\begin{array}{l}\text { Staphylococcus aureus } \\
\text { ATCC } 25923\end{array}$ & $\begin{array}{l}\text { Gram-positive } \\
\text { cocci }\end{array}$ & $\mathrm{MHb}$ & $\mathrm{MH}$ \\
\hline $\begin{array}{l}\text { Staphylococcus aureus } \\
\text { Field strain }\end{array}$ & $\begin{array}{l}\text { Gram-positive } \\
\text { cocci }\end{array}$ & $\mathrm{MHb}$ & $\mathrm{MH}$ \\
\hline $\begin{array}{l}\text { Micrococcus luteus } \\
\text { ATCC } 9341\end{array}$ & $\begin{array}{l}\text { Gram-positive } \\
\text { cocci }\end{array}$ & $\mathrm{MHb}$ & $\mathrm{MH}$ \\
\hline $\begin{array}{l}\text { Pseudomonas aeruginosa } \\
\text { ATCC } 27853\end{array}$ & $\begin{array}{l}\text { Gram-negative } \\
\text { bacilli }\end{array}$ & $\mathrm{MHb}$ & $\mathrm{MH}$ \\
\hline $\begin{array}{l}\text { Escherichia coli } \\
\text { ATCC } 10538\end{array}$ & $\begin{array}{l}\text { Gram-negative } \\
\text { bacilli }\end{array}$ & $\mathrm{MHb}$ & $\mathrm{MH}$ \\
\hline $\begin{array}{l}\text { Candida albicans } \\
\text { ATCC } 10231\end{array}$ & $\begin{array}{l}\text { Gram-positive } \\
\text { yeast }\end{array}$ & $\mathrm{MHb}$ & $\mathrm{MH}$ \\
\hline
\end{tabular}

Abbreviations: $\mathrm{BHI}$, Brain Heart Infusion; BHla, Brain Heart Infusion Agar; $\mathrm{MHb}$, Mueller-Hinton Broth; MH, Mueller-Hinton Medium (Difco Laboratories, Detroit, MI, USA).

were cultivated in BHI and incubated for 24 hours at $37^{\circ} \mathrm{C}$. The other bacteria were cultivated in $\mathrm{MHB}$ and incubated for the same time at the same temperature. The concentration of the inoculum was 0.5 McFarland standard $\left(10^{6-7} \mathrm{cfu} / \mathrm{mL}\right)$.

In each Petri dish, one specimen from each group was placed equidistantly from each other. Subsequently, $15 \mathrm{ml}$ of BHIa or $\mathrm{MH}$ seeded with the indicator microorganism $\left(10^{6-7} \mathrm{cfu} / \mathrm{mL}\right)$ were poured over the specimens. The Petri dishes remained at room temperature for 60 minutes for the antimicrobial agent to diffuse.

The streptococci were incubated in microaerophilia (Gas Pak System, Difco Laboratories, Detroit, MI, USA) and the other bacteria were incubated in aerobiosis $\left(37^{\circ} \mathrm{C} / 24 \mathrm{~h}\right)$. The aspect of the agar on
Table 2 - Test groups and the materials used in each one of them.

\begin{tabular}{c|l|l}
\hline Group & \multicolumn{1}{|l}{ Irreversible hydrocolloid } & Liquid used for the mixture \\
\hline 1 & $\begin{array}{l}\text { Jeltrate (with no added } \\
\text { disinfectant) }\end{array}$ & Sterile distilled water \\
\hline 2 & $\begin{array}{l}\text { Jeltrate (with no added } \\
\text { disinfectant) }\end{array}$ & $\begin{array}{l}0.2 \% \text { aqueous } \\
\text { chlorhexidine digluconate } \\
\text { solution }\end{array}$ \\
\hline 3 & $\begin{array}{l}\text { Greengel (with 0.05\% } \\
\text { diacetate chlorhexidine) }\end{array}$ & Sterile distilled water \\
\hline 4 & $\begin{array}{l}\text { Greengel (with 0.05\% } \\
\text { diacetate chlorhexidine) }\end{array}$ & $\begin{array}{l}0.2 \% \text { aqueous } \\
\text { chlorhexidine digluconate } \\
\text { solution }\end{array}$ \\
\hline
\end{tabular}

and around the specimens was observed with a stereoscopic microscope (Nikon, Tokyo, Japan) under reflected light. The evaluation was conducted for growth or no growth and by measuring the inhibition zone $(\mathrm{mm})$, which was interpreted using an interpretation criteria scale ${ }^{4}$ (Table 3 ). The pool of microorganisms was considered in the interpretation, since they represent a contamination that occurs simultaneously by several microorganisms. Statistical analysis was performed by the normal curve adherence test, which revealed a non-normal distribution. The non-parametric Friedman Test - a type of analysis of variance for two evaluation criteria for linked sample data - was thus performed $(\mathrm{p}<0.05)$.

\section{Results}

Table 4 presents the average inhibition halos $(\mathrm{mm})$ around the specimens and the interpretation in scale (sc) for each triplicate. There was a larger inhibition of the microorganisms in Group 2. In Group 1 (without any antimicrobial agent), it was possible to observe a slight inhibition in the development of some microorganisms. Groups 3 and 4, in which an irreversible hydrocolloid formulated with an antimicrobial agent was mixed with water or with the antimicrobial solution, presented similar behaviors. Based on the statistical analysis, which revealed statistically significant differences among groups $(p<0.05)$, except for groups 3 and 4 , the treatments were classified in the following order of effectiveness: group 1 , group 3 , group 4 , and group 2. 
Table 3 - Interpretation criteria of antimicrobial effect. ${ }^{4}$

\begin{tabular}{|c|c|c|}
\hline Scale & Schematic observation & Aspect of agar \\
\hline 1 & & $\begin{array}{l}\text { Agar layer above the } \\
\text { samples shows the same } \\
\text { growth of the test bacteria } \\
\text { as that of the surrounding } \\
\text { agar. }\end{array}$ \\
\hline 2 & & $\begin{array}{l}\text { On the agar layer above } \\
\text { the samples a few colonies } \\
\text { are observed. Inhibition } \\
\text { of growth is comparable } \\
\text { to that of the surrounding } \\
\text { area. }\end{array}$ \\
\hline & & $\begin{array}{l}\text { No colonies observed on } \\
\text { the agar above the sample. }\end{array}$ \\
\hline 4 & & $\begin{array}{l}\text { There is a definite zone } \\
\text { of inhibition around the } \\
\text { sample no larger than } \\
2.0 \mathrm{~mm} \text {. }\end{array}$ \\
\hline & & $\begin{array}{l}\text { A zone of inhibition of } \\
2.0-5.0 \mathrm{~mm} \text { has developed } \\
\text { around the sample. }\end{array}$ \\
\hline & & $\begin{array}{l}\text { A zone of inhibition of } 5.0 \text { - } \\
10.0 \mathrm{~mm} \text { has developed } \\
\text { around the sample. }\end{array}$ \\
\hline 7 & $\begin{array}{c}\therefore \\
\therefore \\
\therefore\end{array}$ & $\begin{array}{l}\text { A zone of inhibition of } \\
\text { more than } 10.0 \mathrm{~mm} \text { has } \\
\text { developed around the } \\
\text { sample. }\end{array}$ \\
\hline
\end{tabular}

\section{Discussion}

Nowadays, it is unquestionably important to develop procedures to break cross-infection chains, ${ }^{11}$
Table 4 - Results of antimicrobial activity in millimeters (mm) and interpretation criteria scale (sc) ${ }^{4}$

\begin{tabular}{|c|c|c|c|c|c|c|c|c|}
\hline \multirow{2}{*}{ Microorganism } & \multicolumn{2}{|c|}{ Group 1} & \multicolumn{2}{|c|}{ Group 2} & \multicolumn{2}{|c|}{ Group 3} & \multicolumn{2}{|c|}{ Group 4} \\
\hline & $\mathrm{mm}$ & sc & $\mathrm{mm}$ & sc & $\mathrm{mm}$ & sc & $\mathrm{mm}$ & sc \\
\hline $\begin{array}{l}\text { Streptococcus } \\
\text { mutans. } 1 \\
\text { Field strain }\end{array}$ & 2.0 & 5 & 6.0 & 6 & 5.0 & 6 & 6.0 & 6 \\
\hline $\begin{array}{l}\text { Streptococcus } \\
\text { mutans. } 2 \\
\text { Field strain }\end{array}$ & 0.5 & 4 & 4.5 & 5 & 3.5 & 5 & 4.5 & 5 \\
\hline $\begin{array}{l}\text { Streptococcus } \\
\text { sobrinus. } 1 \\
\text { Field strain }\end{array}$ & 2.0 & 5 & 6.0 & 6 & 5.0 & 6 & 5.0 & 6 \\
\hline $\begin{array}{l}\text { Streptococcus } \\
\text { sobrinus. } 2 \\
\text { Field strain }\end{array}$ & 1.0 & 4 & 5.5 & 6 & 5.5 & 6 & 6.5 & 6 \\
\hline $\begin{array}{l}\text { Enterococcus } \\
\text { faecalis } \\
\text { ATCC } 10541\end{array}$ & 0.5 & 4 & 2.0 & 5 & 1.5 & 4 & 4.0 & 5 \\
\hline $\begin{array}{l}\text { Staphylococcus } \\
\text { epidermidis } \\
\text { Field strain }\end{array}$ & 1.0 & 4 & 7.0 & 6 & 3.5 & 5 & 5.0 & 6 \\
\hline $\begin{array}{l}\text { Staphylococcus } \\
\text { aureus } \\
\text { ATCC } 25923\end{array}$ & 0.25 & 4 & 5.5 & 6 & 3.5 & 5 & 5.0 & 6 \\
\hline $\begin{array}{l}\text { Staphylococcus } \\
\text { aureus } \\
\text { Field strain }\end{array}$ & 0.25 & 4 & 6.0 & 6 & 4.0 & 5 & 5.0 & 6 \\
\hline $\begin{array}{l}\text { Micrococcus } \\
\text { luteus } \\
\text { ATCC } 9341\end{array}$ & 0.5 & 4 & 5.5 & 6 & 3.5 & 5 & 5.0 & 6 \\
\hline $\begin{array}{l}\text { Pseudomonas } \\
\text { aeruginosa } \\
\text { ATCC } 27853\end{array}$ & 0.0 & 2 & 0.0 & 2 & 0.0 & 2 & 0.0 & 2 \\
\hline $\begin{array}{l}\text { Escherichia coli } \\
\text { ATCC } 10538\end{array}$ & 0.0 & 3 & 3.5 & 5 & 2.0 & 5 & 3.0 & 5 \\
\hline $\begin{array}{l}\text { Candida } \\
\text { albicans } \\
\text { ATCC } 10231\end{array}$ & 2.5 & 5 & 5.0 & 6 & 0.0 & 2 & 3.5 & 5 \\
\hline
\end{tabular}

such as impression disinfection procedures. In terms of irreversible hydrocolloids, disinfection can be accomplished by several methods, and all present advantages and limitations. In this study, two methods of irreversible hydrocolloid disinfection were evaluated: the incorporation of an antimicrobial agent in the powder and replacement of the water used in the mixture by a disinfectant solution. Regarding the advantages of these techniques, both allow internal disinfection, which eliminates microorganisms that 
are incorporated into the irreversible hydrocolloid during impression-making ${ }^{6,12,13,16}$ as well as during the immediate pouring of the cast.

The results revealed that group 1 (without any antimicrobial agent) had a slight antimicrobial activity against some strains, but it was significantly reduced in relation to that of the other groups $(\mathrm{p}<0.05)$. Possibly, the antimicrobial action was caused by some chemical ingredient of the irreversible hydrocolloid, since sterile distilled water was used for the mixture. However, this activity was reduced and does not exempt the impressions from having to undergo the disinfection procedure, whose importance is unquestionable. . $^{1,411,14}$ The second group in terms of antimicrobial activity was group 3 , in which the impression material formulated with $0.05 \%$ diacetate chlorhexidine was mixed with the water. These results were significantly lower than those of group $2(\mathrm{p}<0.05)$ and are in accordance with those of a previous study, which evaluated the antimicrobial activity of one irreversible hydrocolloid supplemented with a quaternary ammonium compound. ${ }^{7}$ In both studies, most microbial strains were inhibited; however, they were not effective against Candida albicans ATCC 10231 and Pseudomonas aeruginosa ATCC $27853 .{ }^{15}$ Groups 2 and 4 , in which the $0.2 \%$ aqueous digluconate chlorhexidine solution was mixed to an irreversible hydrocolloid respectively without and with $0.05 \%$ diacetate chlorhexidine, showed the largest inhibition of microorganism growth. However, there was a significant difference between them, with the best results being observed for Group 2. Statistical analysis showed that only groups 3 and 4 were not different $(p>0.05)$ in terms of their antimicrobial activity against the evaluated strains.

The antimicrobial efficacy of irreversible hydrocolloids mixed with an antimicrobial solution has also been established by other authors. ${ }^{16}$ In this study, an attempt was made to obtain a synergistic effect by the combination of an antimicrobial agent present in the liquid used for mixing and another one present in the powder (group 4). This association reduced the simulated contamination, but was not better than the material in which chlorhexidine was present only in the liquid used in the mixture (group 2).
The observed antimicrobial action varied between the different strains of the same microorganisms (Table 4). This can be explained by the fact that bacterial populations of the same species behave differently when dealing with antimicrobials, mainly due to the presence of resistance caused by mutation or other genetic mechanisms.

In order to be indicated as a substitute for water, the solution used for the mix must be biocompatible and must not change either the physical or the mechanical properties of the irreversible hydrocolloid. The $0.2 \%$ aqueous chlorhexidine digluconate solution was selected for this research because it fulfills those requirements. ${ }^{13}$ Besides, it is the same antimicrobial agent present in the antimicrobial irreversible hydrocolloid (Greengel). It was thus possible to assess which form of the disinfectant was the best, powder or liquid. It must be considered, however, that the chlorhexidine salts are different, digluconate in liquid and diacetate in powder, and present different solubilities (digluconate is more soluble), ${ }^{5}$ as well as different concentrations $(0.2 \%$ and $0.05 \%$, respectively). Also, since the microorganism inactivation kinetics can be positively correlated with the rate at which the antimicrobial agent gains access to the biophase, the rate of solubility may possibly interfere in the results (group 2 was significantly more effective than group 3).

In the proposed treatments, the response of microorganisms to the chemical agent depends, among others, on the type of microorganism, its susceptibility to the agent, and the time of contact of both. ${ }^{21}$ About the two first factors, the results obtained are consistent with the literature data concerning the antimicrobial agent contained in the powder or liquid, 1,6-di (4-chlorophenyl-diguanido) hexane. This cationic bisbiguanide has broad spectrum efficacy against vegetative Gram-negative and Gram-positive bacteria, some virus and fungi, but none or little effectiveness against spores. Yeasts, such as Candida albicans, are usually sensitive, although the action is subject to species variation. ${ }^{5,8,20}$ In this study, Pseudomonas aeruginosa (Gram negative bacilli) showed no response, probably because this strain is resistant to chlorhexidine. 
Considering the most favorable results, the methods evaluated did not completely inhibit the development of the selected microorganisms. This circumstance is adverse, since the risk of professional contamination by the impressions may still remain.

As to the limitations of this study, it was done with two commercial brands of impression materials and one antimicrobial solution. The field and standard strains used in the test are representative of the oral microbiota, but their behavior in relation to the treatments evaluated must not be extrapolated to other components of the complex oral ecosystem. Nevertheless, taking the limitations into consideration, this study sheds light on a better method of application of an antimicrobial agent in an impression material. Regarding the technique used, ${ }^{2}$ there are, indeed, limitations. However, it has been frequently used to evaluate the antimicrobial activity of dental materials and good results are obtained when the variables of the experiment are controlled. ${ }^{4}$

Further studies in vitro and in vivo are needed in order to supplement the present results. Considering

\section{References}

1. American Dental Association Council on Scientific Affairs and Council on Dental Practice. Infection control recommendations for the dental office and the dental laboratory. $\mathrm{J}$ Am Dent Assoc. 1996;127(5):672-80.

2. Barry AL. Agar diffusion test. In: Barry AL. The antimicrobial susceptibility test: principles and practices. Philadelphia: Lea \& Febiger; 1976. p. 163-213.

3. Bergman B, Bergman M, Olsson S. Alginate impression materials, dimensional stability and surface details sharpness following treatment with disinfectant solutions. Swed Dent J. 1985;9(6):255-62.

4. Brauner AW. In vitro and clinical examination of the effect of an antimicrobial impression material on the oral microflora. Dent Mater. 1990;6(3):201-3.

5. Denton GW. Chlorhexidine. In: Block SS. Disinfection, sterilization and preservation. $4^{\text {th }}$ ed. Philadelphia: Lea \& Febiger; 1991. p. 274-89.

6. Flanagan DA, Palenik CJ, Setcos JC, Miller CH. Antimicrobial activities of dental impression materials. Dent Mater. 1998;14(6):399-404.

7. Ghani F, Hobkirk JA, Wilson M. Evaluation of a new antiseptic-containing alginate impression material. Dent Mater. 1990;169(3-4):83-6. the large number of commercial brands of irreversible hydrocolloids, studies should be conducted to evaluate their compatibility with several antimicrobial agents, in different concentrations, either in the powder or in the liquid used for the mixture. Moreover, investigations of the biological, mechanical, and physical properties of the resulting impression materials are essential to confirm the feasibility of these methods, as well as the effects on the resulting gypsum casts.

\section{Conclusion}

The results of this study suggest that the use of a $0.2 \%$ aqueous digluconate chlorhexidine solution for manipulation of irreversible hydrocolloids was better than the incorporation of $0.05 \%$ diacetate chlorhexidine in the powder in terms of reducing the contamination presented by the impressions. The association of both disinfectant methods did not provide the best results, which were obtained by the group in which the antimicrobial agent was incorporated only in the liquid used for the mixture.

8. Henessey TD. Some antibacterial properties of chlorhexidine. J Periodontal Res. 1973;8(Suppl 12):61-7.

9. Merchant VA, Radcliffe RM, Herrera SP, Stroster TG. Dimensional stability of irreversible hydrocolloid immersed in selected disinfectant solutions. J Am Dent Assoc. 1989;119(4):5335.

10. Poulos JG, Antonoff LR. Disinfection of impressions. Methods and effects on accuracy. NY State Dent J. 1997;63(6):34-6.

11. Powell GL, Runnels RD, Saxon BA, Whisenant BK. The presence and identification of organisms transmitted to dental laboratories. J Prosthet Dent. 1990;64(2):235-7.

12. Ramer MS, Gerhardt DE, McNally K. Accuracy of irreversible hydrocolloid impression materials mixed with disinfectant solutions. J Prosthodont. 1993;2(3):156-8.

13. Rosen M, Touyz LZG. Influence of mixing disinfectant solutions into alginate on working time and accuracy. J Dent. 1991;19(3):186-8.

14. Samaranayake LP, Hunjan M, Jennings KJ. Carriage of oral flora on irreversible hydrocolloid and elastomeric impression materials. J Prosthet Dent. 1991;65(2):244-9.

15. Tobias RS, Browne RM, Wilson CA. An in vitro study of the antibacterial and antifungal properties of an irreversible hydrocolloid impression material impregnated with disinfectant. J Prosthet Dent. 1989;62(5):601-5. 
16. Touyz LZG, Rosen M. Disinfection of alginate impression material using disinfectants as mixing and soak solutions. J Dent. 1991;19(4):255-7.

17. Tullner JB, Commete JA, Moon PC. Linear dimensional changes in dental impressions after immersion in disinfectant solutions. J Prosthet Dent. 1988;60(6):725-8.

18. Tyler R, Tobias RS, Ayliffe GAJ, Browne RM. An in vitro study of the antiviral properties of an alginate impression material impregnated with disinfectant. J Dent. 1989;17(3):1379.
19. Ullsfoss BN, Ogaard B, Arends J, Ruben J, Rölla G, Afseth J. Effect of a combined chlorhexidine and $\mathrm{NaF}$ mouthrinse: an in vivo human caries model study. Scand J Dent Res. 1994;102(2):109-12.

20. Walters TH, Furr JR, Russel AD. Antifungal action of chlorhexidine. Microbios. 1983;38(153-154):195-204.

21. Watkinson AC. Disinfection of impressions in UK dental schools. Br Dent J. 1988;164(1):22-3. 